\title{
EFEKTIVITAS PEMBELAJARAN PERMAINAN ROLE-PLAYING BERBASIS PENGALAMAN UNTUK MENINGKATKAN KETERAMPILAN BERBICARA BAHASA INGGRIS SISWA SEKOLAH DASAR
}

\author{
Saipul Iman ${ }^{1}$, Magfhfirotul Fatha ${ }^{2}$, Saftuni Juliyana ${ }^{3}$ \\ STAI KH. Abdul Kabier \\ saipul.iman77@gmail.com ${ }^{1}$, maghfirotul.ftha@gmail.com ${ }^{2}$, \\ saftuni.j124@gmail.com ${ }^{3}$
}

\begin{abstract}
The purpose of this study was to obtain empirical data on the comparison of the effectiveness between the experience-based role-playing learning method and the method used by teachers (drill) in improving students' speaking skills in English in terms of vocabulary mastery, pronunciation, and interactive communication. The method used in this study is a quasi-experimental using an experimental-control design. The results of this study indicate that the use of the experience-based role-playing game learning method makes a very large contribution in improving students' English speaking skills. The final conclusion is that with the same initial ability between the experimental class and the control class, the use of the experience-based role-playing game learning method in learning English for fifth grade elementary school students is more effective when compared to the drill learning method in learning English in terms of vocabulary mastery., pronunciation and interactive communication.
\end{abstract}

Keywords: Role Playing, Experiential Learning, Speaking Skills.

\begin{abstract}
ABSTRAK
Tujuan penelitian ini adalah untuk memperoleh data empirik tentang perbandingan efektivitas antara metode pembelajaran role-playing berbasis pengalaman dengan metode yang selama ini digunakan oleh guru (drill) dalam meningkatkan keterampilan siswa berbicara bahasa Inggris dilihat dari penguasaan kosakata, pronunciation, dan interactive communication. Metode yang digunakan dalam penelitian ini adalah kuasi eksperimen dengan menggunakan desain eksperimen-kontrol. Hasil penelitian ini menunjukkan bahwa penggunaan metode pembelajaran permainan role-playing berbasis pengalaman memberikan kontribusi yang sangat besar dalam meningkatkan keterampilan berbicara bahasa Inggris siswa. Kesimpulan akhir adalah dengan kemampuan awal yang sama antara kelas eksperimen dan kelas kontrol, penggunaan metode pembelajaran permainan role-playing berbasis pengalaman dalam pembelajaran bahasa Inggris untuk siswa kelas V Sekolah Dasar lebih efektif jika dibandingkan dengan metode pembelajaran drill dalam pembelajaran bahasa Inggris dilihat dari penguasaan vocabulary, pronunciation dan interactive communication.
\end{abstract}

Kata Kunci: Role Playing, Experiential Learning, Keterampilan Berbicara. 


\section{PENDAHULUAN}

Bahasa Inggris merupakan bahasa asing pertama yang dianggap penting untuk tujuan pengaksesan informasi, penyerapan dan pengembangan ilmu pengetahuan, teknologi, seni budaya dan pembinaan hubungan dengan bangsabangsa lain. Menurut Alwasilah (2000: 28), yang mengatakan bahwa tujuan pembelajaran bahasa Inggris di Indonesia adalah: 1) Mempersiapkan pelaku dan pelibat komunikasi abad ke-21 sebagai abad kesejagatan dan persaingan. Penguasaan bahasa asing, khususnya bahasa Inggris adalah strategi kebudayaan agar mereka dapat bersaing dengan bangsa lain. 2) Menyiapkan warga negara yang profesional dan memiliki kesadaran kritis. Manusia kritis mampu berbahasa dengan cermat.

Berdasarkan pendapat di atas dapat disimpulkan bahwa kedudukan bahasa Inggris dalam konteks global adalah sebagai bahasa pergaulan antar bangsa baik dalam politik, sosial, ekonomi maupun kebudayaan. Mengingat penguasaan bahasa Inggris begitu penting dan memiliki kedudukan yang sangat strategis di dalam era globalisasi ini, khususnya dalam upaya memenangkan persaingan global, bahasa Inggris harus diajarkan mulai dari Sekolah Dasar (SD) sampai dengan Perguruan Tinggi (PT). Dengan pengenalan bahasa Inggris dimulai dari Sekolah Dasar (SD) maka siswa akan mengenal dan menguasai bahasa tersebut lebih awal. Oleh karena itu, mereka akan mempunyai pengetahuan dasar yang lebih baik sebelum melanjutkan ke tingkat pendidikan yang lebih tinggi. Dengan demikian secara umum pengajaran bahasa Inggris menjadi mata pelajaran wajib di sekolah-sekolah maupun di Perguruan Tinggi (PT).

Ada beberapa masalah yang menghambat pengajaran bahasa Inggris pada lembaga-lembaga pendidikan formal (sekolah/universitas) khususnya di Sekolah Dasar (SD) yang teridentifikasi di antaranya yaitu bahwa pembelajaran bahasa Inggris pada umumnya masih bersifat konvensional, artinya para guru belum sepenuhnya melaksanakan pembelajaran secara kreatif dan inovatif dan secara umum melulu berisi tentang penguasaan gramatikal, sehingga keterampilan siswa untuk bisa berkomunikasi dengan bahasa Inggris sangat kurang, padahal pada hakikatnya pembelajaran bahasa adalah belajar berkomunikasi, dan tujuan utama dari pembelajaran bahasa Inggris sendiri diarahkan untuk meningkatkan kemampuan siswa dalam berkomunikasi dengan bahasa Inggris baik secara lisan maupun tulisan.

Masalah lainnya yaitu kurangnya motivasi dari siswa untuk mengikuti pembelajaran di kelas, siswa cenderung kurang aktif sehingga menyebabkan pembelajaran bersifat teacher-centered. Ini disebabkan karena kurangnya kemampuan guru untuk menciptakan metode pembelajaran yang menarik yang melibatkan peran serta siswa secara aktif dalam proses pembelajaran.

Ada banyak model pembelajaran menarik yang bisa digunakan oleh para guru untuk meningkatkan motivasi belajar siswa. Untuk siswa Sekolah Dasar, model pembelajaran yang digunakan haruslah sesuai dengan tahap perkembangan siswa itu sendiri. Seperti diketahui bahwa dunia anak adalah dunia bermain, oleh karena itu pembelajaran untuk siswa Sekolah Dasar seharusnya memperhatikan hal tersebut. Permainan yang digunakan dalam proses pembelajaran harus sesuai dengan tingkat perkembangan siswa dan tentunya permainan tersebut adalah permainan yang bersifat edukatif. Oleh karena itu, para guru sebaiknya menjadikan permainan edukatif sebagai proses yang dapat meningkatkan minat, pengetahuan, dan pengalaman anak untuk mempelajari sesuatu. 
Begitu juga dalam pembelajaran bahasa Ingris di Sekolah Dasar (SD), pendekatan dengan menggunakan permainan sangat baik untuk digunakan. Beberapa model pembelajaran dengan memadukan unsur permainan ke dalam proses pembelajaran bahasa Inggris, dianggap dapat meningkatkan keterampilan berbahasa Inggris siswa yang meliputi empat keterampilan berbahasa yakni menyimak, berbicara, membaca, dan menulis.

Dari keempat keterampilan berbahasa Ingris tersebut, saat ini keterampilan berbicara menjadi sorotan utama. Kurangnya kesempatan bagi anak untuk berbicara dengan menggunakan bahasa Inggris baik di sekolah maupun di rumah disinyalir menjadi salah satu penyebabnya. Sejalan dengan hal tersebut, Paul (2007: 76) mengatakan:

The children can listen to English at home, read English at home and even write English at home, but most of them have few opportunities to speak English at home. If we want children to learn to speak English, each of them must have many opportunities to speak during our lessons. They need to practice, practice and practice.

Berdasarkan pendapat di atas dapat disimpulkan bahwa untuk dapat meningkatkan keterampilan berbicara, siswa harus diberikan kesempatan untuk berbicara dengan menggunakan bahasa Inggris seluas-luasnya. Oleh karena itu model pembelajaran yang digunakan haruslah melibatkan peran aktif siswa terutama dalam berbicara, artinya memberikan kesempatan kepada siswa untuk berbicara dengan menggunakan bahasa Inggris pada proses pembelajaran. Untuk siswa Sekolah Dasar (SD), keterlibatan siswa dalam proses pembelajaran akan sangat menarik jika model pembelajaran menggunakan permainan karena sesuai dengan tahap perkembangan siswa, sehingga siswa merasa tertarik dan proses pembelajaran tidak terasa membosankan.

Salah satu model pembelajaran yang melibatkan peran aktif siswa dalam proses pembelajaran adalah model pembelajaran permainan role-playing berbasis pengalaman. Bermain peran (role playing) sebagai suatu model pembelajaran menurut Uno (2008: 26) bertujuan untuk membantu siswa menemukan makna diri (jati diri) di dunia sosial dan memecahkan dilema dengan bantuan kelompok. Artinya dengan bermain peran siswa belajar menggunakan konsep peran, menyadari adanya peran-peran yang berbeda dan memikirkan perilaku dirinya dan perilaku orang lain. Permainan role-playing sebagai model pembelajaran bisa digunakan untuk pembelajaran bahasa Inggris terutama untuk meningkatkan keterampilan berbicara. Hal ini sesuai dengan pendapat Thornbury (2006: 96) yang menyatakan bahwa salah satu strategi pengajaran berbicara (speaking) bahasa Inggris yang efektif adalah role-playing. Senada dengan pendapat Thornbury, Harmer (2002: 274) juga mengatakan bahwa role-playing merupakan strategi pengajaran yang efektif untuk pengajaran berbicara bahasa Inggris, di mana role-playing merupakan salah satu kegiatan berbicara yang bisa dilakukan di dalam kelas dengan menggunakan bahasa Inggris.

Penggunaan permainan role-playing dalam proses pembelajaran menurut Hamalik (2008: 214) merupakan salah satu model pembelajaran yang sesuai digunakan dengan pendekatan berdasarkan pengalaman, di mana pada umumnya kebanyakan siswa usia sembilan tahun atau yang lebih tua menyenangi penggunaan model ini, karena berkenaan dengan isu-isu sosial dan kesempatan komunikasi interpersonal di dalam kelas dengan menggunakan bahasa Inggris.

Pendekatan pembelajaran berbasis pengalaman (experiential learning) menyediakan kesempatan kepada siswa untuk melakukan kegiatan-kegiatan 
belajar secara aktif dengan personalisasi. pendekatan pembelajaran berbasis pengalaman (experiential learning) memberi para siswa seperangkat/serangkaian situasi-situasi belajar dalam bentuk keterlibatan pengalaman sesungguhnya yang dirancang oleh guru. Menurut Hamalik (2001: 212) tujuan pendidikan yang mendasari strategi ini adalah:

1) Untuk menambah rasa percaya diri dan kemampuan pelajar melalui partisipasi belajar aktif (berlawanan dengan partisifasi pasif);

2) Untuk menciptakan interaksi sosial yang positif guna memperbaiki hubungan sosial dalam kelas.

Strategi ini dilandasi oleh teori John Dewey, yakni prinsip belajar sambil berbuat (learning by doing). Prinsip ini berdasarkan asumsi bahwa para siswa dapat memperoleh lebih banyak pengalaman belajar dengan cara keterlibatan secara aktif dan personal, jika dibandingkan dengan hanya melihat materi/konsep.

\section{METODE PENELITIAN}

Penelitian ini menggunakan metode penelitian kuantitatif yang jenisnya adalah kuasi eksperimen. Kuasi eksperimen telah dipilih menjadi metode penelitian ini karena sesuai dengan hakekat penelitian yang akan dilakukan, yaitu untuk mengontrol dan atau memanipulasi semua variabel yang relevan. Desain penelitian yang dipergunakan adalah nonequivalent control group design dengan pre-test dan post-test. Menurut Sugiono (2009: 116), desain ini hampir sama dengan pretest-postest control group design, hanya pada desain ini kelompok eksperimen maupun kelompok kontrol tidak dipilih secara random.

Dalam penelitian ini, kelas eksperimen diberikan perlakuan dengan menggunakan metode pembelajaran permainan role-playing berbasis pengalaman, sedangkan kelompok kontrol diberikan perlakuan metode pembelajaran yang selama ini dilakukan oleh guru, yaitu metode pembelajaran dengan drill. Populasi sasaran dalam penelitian ini adalah seluruh siswa Sekolah Dasar Negeri (SDN) Cilayang III dan Sekolah Dasar Negeri (SDN) Cimaung III Kecamatan Cikeusal Kabupaten Serang, dan populasi terjangkaunya adalah siswa kelas V.

\section{HASIL DAN PEMBAHASAN}

\section{Pada Keterampilan Berbicara dari Segi Penguasaan Kosakata (Vocabulary)}

Data yang didapat dari hasil perhitungan uji-t dengan menggunakan SPSS (lihat tabel 22, 23, dan 24) diperoleh gain skor eksperimen dan skor kontrol pada keterampilan berbicara bahasa Inggris dilihat dari segi penguasaan kosakata (vocabulary) yang dilakukan terhadap siswa kelas V Sekolah Dasar Negeri (SDN) Cilayang III sebanyak 20 orang sebagai kelas eksperimen dan siswa kelas V Sekolah Dasar Negeri (SDN) Cimaung III sebanyak 20 orang sebagai kelas kontrol, yakni untuk siswa kelas eksperimen memiliki nilai gain 39.5, sedangkan untuk siswa kelas kontrol memiliki nilai gain 23. 
Tabel 22

Paired Samples Statistic Vocabulary

Paired Samples Statistics

\begin{tabular}{|c|c|c|c|c|c|}
\hline & & Mean & $\mathrm{N}$ & $\begin{array}{c}\text { Std. } \\
\text { Deviation }\end{array}$ & $\begin{array}{l}\text { Std. Error } \\
\text { Mean }\end{array}$ \\
\hline \multirow[t]{2}{*}{ Pair 1} & $\begin{array}{l}\text { Skor Gain Eksperimen } \\
\text { Vocabulary }\end{array}$ & 39.5000 & 20 & 13.16894 & 2.94467 \\
\hline & $\begin{array}{l}\text { Skor Gain Kontrol } \\
\text { Vocabulary }\end{array}$ & 23.0000 & 20 & 10.80935 & 2.41704 \\
\hline
\end{tabular}

Tabel 23

Paired Samples Correlations Vocabulary Paired Samples Correlations

\begin{tabular}{|ll|c|c|c|}
\hline & N & Correlation & Sig. \\
\hline Pair 1 & $\begin{array}{l}\text { Skor Gain Eksperimen } \\
\text { Vocabulary \& Skor Gain } \\
\text { Kontrol Vocabulary }\end{array}$ & 20 & .233 & .323 \\
\hline
\end{tabular}

Tabel 24

Paired Samples Test Vocabulary

Paired Samples Test

\begin{tabular}{|c|c|c|c|c|c|c|c|c|c|}
\hline & \multicolumn{5}{|c|}{ Paired Differences } & \multirow{3}{*}{$\mathrm{t}$} & \multirow{3}{*}{ df } & \multirow{3}{*}{$\begin{array}{l}\text { Sig. } \\
(2- \\
\text { tailed })\end{array}$} \\
\hline & & \multirow[t]{2}{*}{ Mean } & \multirow{2}{*}{$\begin{array}{c}\text { Std. } \\
\text { Deviati } \\
\text { on }\end{array}$} & \multirow{2}{*}{$\begin{array}{l}\text { Std. } \\
\text { Error } \\
\text { Mean }\end{array}$} & \multicolumn{2}{|c|}{$\begin{array}{l}95 \% \text { Confidence } \\
\text { Interval of the } \\
\text { Difference }\end{array}$} & & & \\
\hline & & & & & Lower & Upper & & & \\
\hline $\begin{array}{l}\text { Pair } \\
1\end{array}$ & $\begin{array}{l}\text { Skor Gain } \\
\text { Eksperime } \\
\mathrm{n} \\
\text { Vocabular } \\
\text { y - Skor } \\
\text { Gain } \\
\text { Kontrol } \\
\text { Vocabular } \\
\text { y }\end{array}$ & $1.65000 \mathrm{E} 1$ & $\mid \begin{array}{c}14.9648 \\
7\end{array}$ & 3.34625 & 9.49622 & 23.50378 & $\begin{array}{c}4.93 \\
1\end{array}$ & 19 & .000 \\
\hline
\end{tabular}

Untuk menunjukkan adanya korelasi antara kedua variabel pengajaran keterampilan bahasa Inggris dari segi penguasaan kosakata (vocabulary) baik dalam kelas eksperimen maupun kelas kontrol dapat dilihat pada tabel 23 yang menghasilkan angka korelasi 0.233 dengan nilai probabilitas di bawah 0.05 (lihat nilai signifikansi output yang 0.000). Hal ini menyatakan bahwa korelasi antara nilai gain siswa pada hasil tes kelas eksperimen dan kelas kontrol pada pengajaran keterampilan berbicara bahasa Inggris dilihat dari segi penguasaan kosakata (vocabulary) adalah cukup erat dan benar-benar berhubungan secara nyata.

Selanjutnya berdasarkan hasil uji beda dengan menggunakan t-tes menunjukkan bahwa t-hitung terletak pada daerah Ho ditolak, sehingga dapat 
diambil kesimpulan bahwa nilai gain post-test kelas eksperimen yang menggunakan perlakuan model pembelajaran permainan role-playing berbasis pengalaman dengan kelas kontrol yang menggunakan perlakuan metode drill untuk keterampilan berbicara dilihat dari segi penguasaan kosakata (vocabulary) relatif berbeda.

Sementara itu tinjauan kriteria efektivitas berdasarkan Kriteria Ketuntasan Minimal (KKM) menunjukkan bahwa skor rata-rata yang diperoleh kelas eksperimen adalah 86 berada di atas KKM, dan siswa yang memperoleh skor sama atau di atas KKM berjumlah 20 orang (100\%).

Berdasarkan hasil analisis dari beberapa faktor di atas, dapat disimpulkan bahwa penggunaan model pembelajaran permainan role-playing berbasis pengalaman lebih efektif dalam meningkatkan keterampilan siswa berbicara bahasa Inggris dilihat dari segi penguasaan kosakata (vocabulary) dibandingkan dengan metode pembelajaran yang selama ini dilakukan oleh guru, yaitu model drill.

\section{Pada Keterampilan Berbicara dari Segi Pronunciation}

Berdasarkan perhitungan uji-t dengan SPSS (tabel 25, 26, dan 27) diperoleh gain skor eksperimen dan skor kontrol pada keterampilan berbicara bahasa Inggris dilihat dari segi pronunciation yang dilakukan terhadap siswa kelas V Sekolah Dasar Negeri (SDN) Cilayang III sebanyak 20 orang sebagai kelas eksperimen dan siswa kelas V Sekolah Dasar Negeri (SDN) Cimaung III sebanyak 20 orang sebagai kelas kontrol, yakni untuk siswa kelas eksperimen memiliki nilai gain 28.5 dan untuk siswa kelas kontrol memiliki nilai gain 21.5, sedangkan untuk menunjukkan adanya korelasi antara kedua variabel pengajaran keterampilan bahasa Inggris dari segi pronunciation baik dalam kelas eksperimen maupun kelas kontrol dapat dilihat pada tabel 26 halaman 151, yang menghasilkan angka 0.150 dengan nilai probabilitas di bawah 0.05 (lihat nilai signifikansi output yang 0.044). Hal ini menyatakan bahwa korelasi antara nilai gain siswa pada hasil tes kelas eksperimen dan kelas kontrol pada pengajaran keterampilan berbicara bahasa Inggris dilihat dari segi pronunciation adalah cukup erat dan benar-benar berhubungan secara nyata.

Tabel 25

Paired Samples Statistics Pronounciation Paired Samples Statistics

\begin{tabular}{|c|c|c|c|c|c|}
\hline & & Mean & $\mathrm{N}$ & $\begin{array}{c}\text { Std. } \\
\text { Deviation }\end{array}$ & $\begin{array}{l}\text { Std. Error } \\
\text { Mean }\end{array}$ \\
\hline \multirow[t]{2}{*}{ Pair 1} & $\begin{array}{l}\text { Skor Gain Eksperimen } \\
\text { Pronounciation }\end{array}$ & 28.5000 & 20 & 12.25819 & 2.74101 \\
\hline & $\begin{array}{l}\text { Skor Gain Kontrol } \\
\text { Pronounciation }\end{array}$ & 21.5000 & 20 & 9.88087 & 2.20943 \\
\hline
\end{tabular}


Tabel 26

Paired Samples Correlations Pronounciation

Paired Samples Correlations

\begin{tabular}{|ll|c|c|c|}
\hline & N & Correlation & Sig. \\
\hline Pair 1 & $\begin{array}{l}\text { Skor Gain Eksperimen } \\
\text { Pronounciation \& Skor Gain } \\
\text { Kontrol Pronounciation }\end{array}$ & 20 & .150 & .528 \\
\hline
\end{tabular}

Tabel 27

Paired Samples Test Pronounciation

Paired Samples Test

\begin{tabular}{|c|c|c|c|c|c|c|c|c|c|}
\hline & \multicolumn{5}{|c|}{ Paired Differences } & \multirow{3}{*}{$\mathrm{t}$} & \multirow{3}{*}{ df } & \multirow{3}{*}{$\begin{array}{l}\text { Sig. (2- } \\
\text { tailed) }\end{array}$} \\
\hline & & \multirow[t]{2}{*}{ Mean } & \multirow{2}{*}{$\begin{array}{c}\text { Std. } \\
\text { Deviatio } \\
\mathrm{n}\end{array}$} & \multirow{2}{*}{$\begin{array}{l}\text { Std. } \\
\text { Error } \\
\text { Mean }\end{array}$} & \multicolumn{2}{|c|}{$\begin{array}{c}95 \% \text { Confidence } \\
\text { Interval of the } \\
\text { Difference }\end{array}$} & & & \\
\hline & & & & & Lower & Upper & & & \\
\hline $\begin{array}{l}\text { Pair } \\
1\end{array}$ & $\begin{array}{l}\text { Skor Gain } \\
\text { Eksperimen } \\
\text { Pronounciation } \\
\text { - Skor Gain } \\
\text { Kontrol } \\
\text { Pronounciation }\end{array}$ & 7.00000 & 14.54575 & 3.25253 & .19238 & $\begin{array}{c}13.8076 \\
2\end{array}$ & $\begin{array}{c}2.15 \\
2\end{array}$ & 19 & .044 \\
\hline
\end{tabular}

Sementara itu berdasarkan hasil uji beda dengan menggunakan t-tes menunjukkan bahwa t-hitung terletak pada daerah Ho ditolak, sehingga dapat diambil kesimpulan bahwa nilai gain post-test kelas eksperimen setelah mendapatkan perlakuan model pembelajaran permainan role-playing berbasis pengalaman dengan kelas kontrol setelah mendapatkan perlakuan metode drill untuk keterampilan berbicara dilihat dari segi penguasaan pronunciation relatif berbeda.

Pada tinjauan ketercapaian kriteria efektivitas berdasarkan Kriteri Ketuntasan Minimal (KKM) diperoleh skor rata-rata yang diperoleh kelas eksperimen adalah 74 berada di atas KKM, dan siswa yang memperoleh skor sama atau di atas KKM berjumlah 16 orang (80\%).

Berdasarkan hasil analisis dari beberapa faktor di atas, dapat disimpulkan bahwa penggunaan model pembelajaran permainan role-playing berbasis pengalaman lebih efektif dalam meningkatkan keterampilan siswa berbicara bahasa Inggris dilihat dari segi pronunciation dibandingkan dengan metode pembelajaran yang selama ini dilakukan oleh guru, yaitu model drill.

\section{Pada Keterampilan Berbicara dari Segi Interactive Communication}

Data yang didapat dari hasil perhitungan uji-t dengan SPSS (tabel 28, 29, dan 30) diperoleh gain skor eksperimen dan skor kontrol pada keterampilan berbicara bahasa Inggris dilihat dari segi interactive communication yang dilakukan terhadap siswa kelas V Sekolah Dasar Negeri (SDN) Cilayang III sebanyak 20 orang sebagai kelas eksperimen dan siswa kelas V Sekolah Dasar Negeri (SDN) Cimaung III sebanyak 20 orang sebagai kelas kontrol, yakni untuk 
siswa kelas eksperimen memiliki nilai gain 25 dan untuk siswa kelas kontrol memiliki nilai gain 16.

Tabel 28

Paired Samples Statistics Interactive Communication

Paired Samples Statistics

\begin{tabular}{|c|c|c|c|c|c|}
\hline & & Mean & $\mathrm{N}$ & $\begin{array}{c}\text { Std. } \\
\text { Deviation }\end{array}$ & $\begin{array}{l}\text { Std. Error } \\
\text { Mean }\end{array}$ \\
\hline \multirow{2}{*}{ Pair 1} & $\begin{array}{l}\text { Skor Gain } \\
\text { Eksperimen } \\
\text { Interactive Com }\end{array}$ & 25.0000 & 20 & 11.92079 & 2.66557 \\
\hline & $\begin{array}{l}\text { Skor Gain Kontrol } \\
\text { Interactive } \\
\text { Communication }\end{array}$ & 16.0000 & 20 & 9.40325 & 2.10263 \\
\hline
\end{tabular}

Tabel 29

Paired Samples Correlations Interactive Communication

Paired Samples Correlations

\begin{tabular}{|ll|c|c|c|}
\hline & $\mathrm{N}$ & Correlation & Sig. \\
\hline Pair 1 & $\begin{array}{l}\text { Skor Gain Eksperimen } \\
\text { Intrctve Com \& Skor Gain } \\
\text { Kontrol Intrctve Com }\end{array}$ & 20 & .892 & .000 \\
\hline
\end{tabular}

Tabel 30

Paired Samples Test Interactive Communication

Paired Samples Test

\begin{tabular}{|c|c|c|c|c|c|c|c|c|c|}
\hline & \multicolumn{5}{|c|}{ Paired Differences } & \multirow{3}{*}{$\mathrm{t}$} & \multirow{3}{*}{ df } & \multirow{3}{*}{$\begin{array}{l}\text { Sig. } \\
(2- \\
\text { tailed })\end{array}$} \\
\hline & & \multirow[t]{2}{*}{ Mean } & \multirow{2}{*}{$\begin{array}{c}\text { Std. } \\
\text { Deviati } \\
\text { on }\end{array}$} & \multirow{2}{*}{$\begin{array}{l}\text { Std. } \\
\text { Error } \\
\text { Mean }\end{array}$} & \multicolumn{2}{|c|}{$\begin{array}{l}95 \% \text { Confidence } \\
\text { Interval of the } \\
\text { Difference }\end{array}$} & & & \\
\hline & & & & & Lower & Upper & & & \\
\hline $\begin{array}{l}\text { Pair } \\
1\end{array}$ & $\begin{array}{l}\text { Skor Gain } \\
\text { Eksperimen } \\
\text { Interactive } \\
\text { Communication - } \\
\text { Skor Gain Kontrol } \\
\text { Interactive } \\
\text { Communication }\end{array}$ & 9.00000 & 5.52506 & 1.23544 & 6.41419 & $\begin{array}{c}11.5858 \\
1\end{array}$ & $\begin{array}{c}7.28 \\
5\end{array}$ & 19 & .000 \\
\hline
\end{tabular}

Untuk menunjukkan adanya korelasi antara kedua variabel pengajaran keterampilan bahasa Inggris dari segi interactive communication baik dalam kelas eksperimen maupun kelas kontrol bisa dilihat pada tabel 29, yang menghasilkan angka 0.892 dengan nilai probabilitas di bawah 0.05 (lihat nilai signifikansi output yang 0.000). Hal ini menyatakan bahwa korelasi antara nilai gain siswa pada hasil tes kelas eksperimen dan kelas kontrol pada pengajaran keterampilan 
berbicara bahasa Inggris dilihat dari segi interactive communication adalah cukup erat dan benar-benar berhubungan secara nyata.

Sedangkan berdasarkan hasil uji beda dengan menggunakan t-tes juga menunjukkan bahwa t-hitung terletak pada daerah Ho ditolak, sehingga dapat diambil kesimpulan bahwa nilai gain post-test kelas eksperimen yang menggunakan perlakuan model pembelajaran permainan role-playing berbasis pengalaman dengan kelas kontrol yang menggunakan perlakuan metode drill untuk keterampilan berbicara dilihat dari segi penguasaan interactive communication relatif berbeda.

Selanjutnya berdasarkan tinjauan ketercapaian kriteria efektivitas berdasarkan Kriteria Ketuntasan Minimal (KKM) diperoleh skor rata-rata kelompok eksperimen adalah 81 berada di atas KKM, dan siswa yang memperoleh skor sama atau di atas KKM berjumlah 17 orang $(85 \%)$.

Berdasarkan hasil analisis dari beberapa faktor tersebut di atas, dapat ditarik kesimpulan bahwa penggunaan model pembelajaran permainan roleplaying berbasis pengalaman lebih efektif dalam meningkatkan keterampilan siswa berbicara bahasa Inggris dilihat dari segi interactive communication dibandingkan dengan metode pembelajaran yang selama ini dilakukan oleh guru, yaitu model drill.

Dalam role-playing siswa terlibat aktif dalam proses pembelajaran, di mana penggunaan bahasa Inggris pada saat role-playing telah memberikan kesempatan yang seluas-luasnya kepada siswa untuk berlatih berbicara bahasa Inggris di dalam kelas, sementara itu kesempatan berlatih berbicara dalam bahasa Inggris di rumah hampir tidak dimiliki siswa. Kurangnya kesempatan inilah yang menjadi hambatan terbesar siswa dalam berbicara bahasa Inggris sebagai bahasa asing. Hal ini sejalan dengan pendapat yang dikemukakan oleh Paul (2007: 76) bahwa:

The children can listen to English at home, read English at home and even write English at home, but most of them have few opportunities to speak English at home. If we want children to learn to speak English, each of them must have many opportunities to speak during our lessons. They need to practice, practice and practice.

Di sini jelas bahwa jika menginginkan siswa belajar berbicara bahasa Inggris dengan lebih efektif, maka siswa harus diberi kesempatan untuk berbicara menggunakan bahasa Inggris seluas-luasnya.

Hal ini juga sejalan dengan pendapat yang dikemukakan oleh Brown dan Yule (dalam Nunan, 1989: 27) yang mengatakan bahwa pengajaran bahasa untuk pengembangan ranah keterampilan berbicara sebaiknya memfokuskan perhatiannya pada pengembangan keterampilan melakukan dialog yang memang saling mempertukarkan kegiatan interaksional.

Berdasarkan hasil pengujian hipotesis, ternyata hipotesis kerja secara umum yang diajukan diterima. Terlihat dalam hasil perhitungan analisis statistik yang menyatakan bahwa gain skor tes pada keterampilan berbicara dari segi penguasaan vocabulary, pronunciation, dan interactive communication menunjukkan perbedaan yang berarti. Hal ini menunjukkan bahwa penggunaan model pembelajaran permainan role-playing berbasis pengalaman memberikan pengaruh yang signifikan dibandingkan dengan yang menggunakan metode $d r i l l$.

Peningkatan keterampilan berbicara bahasa Inggris siswa baik dari segi penguasaan kosakata (vocabulary), pronunciation maupun interactive 
communication dapat diakibatkan oleh penggunaan model pembelajaran permainan role-playing berbasis pengalaman. Hal ini sesuai dengan pendapat Thornbury (2006: 96) yang menyatakan bahwa salah satu strategi pengajaran berbicara (speaking) bahasa Inggris yang efektif adalah role-playing. Senada dengan pendapat Thornbury, Harmer (2002: 274) juga mengatakan bahwa roleplaying merupakan strategi pengajaran yang efektif untuk pengajaran berbicara bahasa Inggris, di mana role-playing merupakan salah satu kegiatan berbicara yang bisa dilakukan di dalam kelas dengan menggunakan bahasa Inggris. Selanjutnya menurut Harmer (2002: 275) dengan role-playing siswa dapat mengungkapkan apa yang mereka pikirkan dan rasakan dengan menggunakan bahasa Inggris.

Harmer (2002: 275) juga berpendapat bahwa pembelajaran role-playing memiliki beberapa keuntungan diantaranya yaitu:

In the first place they can be good fun and thus motivating. Second, they allow hesitant students to be more forthright in their opinions and behavior than they might be when speaking for themselves, since they do not have to take the same responsibility for what they are saying. Third, by broadening the world of the classroom to include the world outside, they allow students to use a much wider range of language than some more task centred activities may do.

Berdasarkan pendapat di atas jelaslah bahwa role-playing memiliki banyak keuntungan dalam meningkatkan keterampilan berbicara bahasa Inggris siswa karena di samping bersifat menyenangkan dan menambah motivasi siswa dalam belajar bahasa Inggris, juga memberikan kebebasan kepada siswa untuk mengemukakan pendapatnya tanpa harus bertanggung jawab atas apa yang mereka ucapkan karena role-playing hanya bersifat permainan.

Penggunaan permainan role-playing dalam proses pembelajaran menurut Hamalik (2008: 214) merupakan salah satu model pembelajaran yang sesuai digunakan dengan pendekatan berdasarkan pengalaman, di mana pada umumnya kebanyakan siswa usia sembilan tahun atau yang lebih tua menyenangi penggunaan model ini, karena berkenaan dengan isu-isu sosial dan kesempatan komunikasi interpersonal di dalam kelas dengan menggunakan bahasa Inggris. Senada dengan Hamalik, Celce-Murcia (1991: 349) juga mengatakan bahwa salah role-playing merupakan strategi pembelajaran bahasa Inggris yang bisa digunakan dengan pendekatan berdasarkan pengalaman, di mana role-playing merupakan salah satu jenis kegiatan berdasarkan pengalaman yang dilakukan di dalam kelas yang dikontrol oleh siswa. Dalam kegiatan ini siswa menjadi lebih aktif terlibat dalam perencanaan dan pemantauan kegiatan, sedangkan guru hanya memiliki sedikit kontrol atas hasil pembelajaran. Meskipun kegiatan ini masih terbatas pada kelas, tetapi lebih bersifat terbuka dan menantang daripada kegiatan lainnya.

Penggunaan permainan role play dalam pembelajaran bahasa Inggris memberikan kesempatan kepada siswa untuk berlatih speaking (berbicara) bahasa Inggris di dalam kelas, ini terbukti sangat efektif untuk meningkatkan keterampilan berbicara bahasa Inggris. Role-playing dapat menimbulkan kesenangan kepada siswa karena pada dasarnya role-playing adalah permainan. Dengan bermain siswa akan merasa senang karena bermain adalah dunia anak, apalagi jika role-playing yang digunakan dalam pembelajaran didasarkan pada pengalaman siswa dalam kehidupan sehari-hari, sehingga siswa akan mudah menyerap materi yang diajarkan. 
Program pembelajaran yang dikemas dalam permainan role-playing berbasis pengalaman dengan unsur kebahasaan keterampilan berbicara dilihat dari penguasaan vocabulary, pronunciation dan interactive communication memberikan pengalaman belajar yang bermakna terhadap siswa dalam belajar bahasa Inggris, kebermaknaan siswa dirasakan ketika siswa ingin melakukan kegiatan role-playing secara berulang-ulang. Pada saat itu siswa berani mengungkapkan apa yang mereka pikirkan dan rasakan dengan menggunakan bahasa Inggris, walaupun pada awalnya mereka masih belum berani melakukannya. Hal ini diperkuat dengan data yang diperoleh melalui angket motivasi yang disebarkan setelah penggunaan pembelajaran permainan roleplaying berbasis pengalaman kepada kelas eksperimen.

Dari data yang diperoleh bahwa semua siswa yang berjumlah 20 orang mengatakan bahwa mereka semuanya menyukai model pembelajaran permainan role-playing berbasis pengalaman dengan berbagai alasan sebagai berikut:

a. Permainannya menyenangkan.

b. Bisa membuat pintar.

c. Tidak membosankan.

d. Bisa belajar dan bermain.

e. Sangat mengasikan.

f. Menyenangkan dan tidak membosankan.

g. Bisa melatih berbicara.

h. Menambah pengalaman belajar.

i. Bisa bermain dengan menggunakan bahasa Inggris

Berdasarkan hasil angket yang diberikan terhadap siswa kelompok eksperimen, dapat disimpulkan bahwa semua siswa yang berada di kelas eksperimen $(100 \%)$ sangat menyukai pembelajaran permainan role-playing berbasis pengalaman, dan hampir semua siswa menyukai materi yang diajarkan. Bila dihubungkan dengan hasil pre-test dan post-test dari masing-masing materi yang disajikan, dapat disimpulkan bahwa pembelajaran permainan role-playing berbasis pengalaman lebih efektif jika dibandingkan dengan pembelajaran dengan menggunakan metode drill.

\section{KESIMPULAN}

Penelitian ini berusaha untuk mengkaji efektivitas model pembelajaran permainan role-playing berbasis pengalaman dalam meningkatkan keterampilan berbicara bahasa Inggris siswa Sekolah Dasar dilihat dari segi penguasaan kosakata (vocabulary), pronounciation, dan interactive communication.

Berdasarkan hasil penelitian dan pembahasan, diperoleh butir-butir simpulan sebagai berikut:

1. Terdapat perbedaan yang signifikan dalam peningkatan keterampilan berbicara bahasa Inggris siswa di lihat dari segi penguasaan kosakata (vocabulary) setelah siswa diberikan perlakuan dengan menggunakan model pembelajaran permainan role-playing berbasis pengalaman jika dibandingkan dengan keterampilan berbicara bahasa Inggris siswa yang mendapatkan perlakuan dengan metode drill. Ini disebabkan karena dalam model pembelajaran permainan role-playing berbasis pengalaman, siswa memiliki kesempatan lebih banyak untuk berlatih berbicara di dalam kelas dengan proses belajar yang sangat menyenangkan. Model pembelajaran ini juga menghadirkan suatu pengalaman hidup yang pernah siswa alami di kehidupan nyata ke dalam kelas dengan memadukan unsur permainan ke 
dalam proses belajar mengajarnya, sehingga siswa akan lebih mudah mengingat materi yang telah dipelajari. Kosakata (vocabulary) yang digunakan dalam role-playing akan lebih mudah diingat karena dalam roleplaying siswa tidak hanya mengucapkannya akan tetapi juga melakukan apa yang diucapkannya secara langsung dengan cara yang menyenangkan.

2. Terdapat perbedaan yang signifikan dalam peningkatan keterampilan berbicara bahasa Inggris siswa di lihat dari segi pronounciation setelah siswa diberikan perlakuan dengan menggunakan model pembelajaran permainan role-playing berbasis pengalaman jika dibandingkan dengan keterampilan berbicara bahasa Inggris siswa yang mendapatkan perlakuan dengan metode drill. Ini disebabkan karena dalam model pembelajaran permainan role-playing berbasis pengalaman, siswa memiliki kesempatan lebih banyak untuk berlatih berbicara di dalam kelas dan terlibat aktif dalam proses belajar mengajar. Belajar bahasa Inggris pada dasarnya bertujuan agar bisa berkomunikasi dengan menggunakan bahasa Inggris, sehingga apa yang dikatakan bisa dimengerti oleh orang yang diajak berbicara. Karena bahasa Inggris merupakan bahasa asing, maka pengucapannya, baik intonasi, penekanan maupun ejaannya harus sesuai dengan penutur aslinya, dan ini membutuhkan banyak latihan agar pengucapannya sesuai dengan penutur aslinya. Dalam hal ini, role-playing merupakan salah satu model pembelajaran yang memberikan kesempatan kepada siswa untuk berlatih berbicara bahasa Inggris dari segi pronounciation, karena dalam roleplaying siswa tidak hanya berbicara untuk diri sendiri akan tetapi berkomunikasi dengan orang yang diajak berbicara sehingga pengucapannya harus benar supaya informasi yang ingin disampaikan oleh pembicara bisa tersampaikan pada orang yang diajak berbicara.

3. Terdapat perbedaan yang signifikan dalam peningkatan keterampilan berbicara bahasa Inggris siswa di lihat dari segi interactive communication setelah siswa diberikan perlakuan dengan menggunakan model pembelajaran permainan role-playing berbasis pengalaman jika dibandingkan dengan keterampilan berbicara bahasa Inggris siswa yang mendapatkan perlakuan dengan metode drill. Ini disebabkan karena dalam model pembelajaran permainan role-playing berbasis pengalaman, siswa memiliki kesempatan lebih banyak untuk berlatih berbicara di dalam kelas dan terlibat aktif dalam proses belajar mengajar. Belajar bahasa Inggris pada dasarnya bertujuan agar bisa berkomunikasi dengan menggunakan bahasa Inggris. Oleh karena itu, pembicara dituntut tidak hanya bisa bertanya akan tetapi juga harus bisa menjawab pertanyaan lawan bicara, sehingga adanya interaksi di antara keduanya. Kemampuan untuk bisa berinteraksi dengan orang lain menggunakan bahasa Inggris kurang efektif jika dilakukan hanya dengan berlatih sendiri tetapi memerlukan lawan bicara untuk saling berinteraksi. Dalam role-playing, siswa dihadapkan pada situasi di mana siswa harus saling berinteraksi dengan siswa lain yang menjadi partisipan dalam role-playing, sehingga role-playing bisa berjalan lancar. Inilah yang menjadikan role-playing menjadi salah satu model pembelajaran yang efektif dalam meningkatkan keterampilan berbicara bahasa Inggris dilihat dari segi interactive communication.

Model pembelajaran permainan role-playing berbasis pengalaman memiliki beberapa keunggulan di antaranya yaitu: siswa memiliki kesempatan lebih banyak untuk berlatih dalam berbicara bahasa Inggris di dalam kelas; siswa 
lebih cepat mengingat kosakata yang diajarkan karena kegiatan role-playing didasarkan pada pengalaman siswa dalam kehidupan nyata; siswa memiliki kebebasan untuk mengemukakan apa yang dirasakan dan dipikirkan saat itu tanpa harus bertanggung jawab atas perkataannya; dan meningkatkan keterampilan siswa dalam bersosialisasi.

Selain memiliki keunggulan, role-playing juga memiliki kelemahan, yaitu: siswa tidak bisa melakukan role-playing tanpa pemanasan terlebih dahulu sehingga memerlukan waktu yang cukup banyak dalam proses pembelajaran; pada awal kegiatan role-playing, kebanyakan siswa belum berani melakukannya; dan untuk kelas dengan siswa yang lebih banyak membutuhkan waktu yang cukup banyak untuk dapat memberikan kesempatan kepada semua siswa melakukan kegiatan role-playing.

\section{DAFTAR PUSTAKA}

Alwasilah, A.C. (2000). Persfektif Pendidikan Bahasa Inggris di Indonesia Dalam Konteks Persaingan Global. Bandung: CV Andira.

Ali, Mohamad. (1982). Penelitian Kependidikan, Prosedur dan Strategi. Bandung: Angkasa.

Aunurrahman. (2009). Belajar dan Pembelajaran. Bandung: Alfabeta.

Budiningsih, C.A. (2005). Belajar dan pembelajaran. Jakarta: Rineka Cipta.

Cahyani, I (2009). Peran Experiential Learning dalam Meningkatkan Motivasi Pembelajar BIPA. Tersedia online pada http://www.ialf.edu.kipbipa/papers/CahyaniIsah.doc). Tanggal 23 April 2010)

Cameron, L. (2003). Teaching Languages to Young Learners. Cambridge: Cambridge University Press.

Cohen, A.D. (1998). Strategies in Learning and Using A Second Language. New York: Longman.

Dewey, J. (1996). Democracy and Education. New York: A Free Press Paperback Macmillan Publishing Co., Inc.

Hajar, S (1996). Permainan Bahasa Dalam Pengajaran dan Pembelajaran. Tersedia online di http://cari.pdf.com/pdf.php?q=permainan+bahasa. Tanggal 15 Februari 2010.

Harmer, Jeremy. (2002). The Practice of English Language Teaching. New York: Longman.

Hamalik, Oemar. (1988). Pendekatan Strategi Belajar Mengajar CBSA. Bandung: Sinar Baru Algesndo).

Hamalik, Oemar. (2008). Proses Belajar Mengajar. Jakarta: Bumi Aksara.

Iskandarwasid dan Sunendar, D. (2008). Strategi Pembelajaran Bahasa. Bandung : Remaja Rosda Karya.

Ismail, A. (2006). Education Games, Menjadi Cerdas dan Ceria Dengan Permainan Edukatif. Yogyakarta: Pilar Media.

Jonckheere, B.A. (2006). Experiential Learning Through "Reality" English. Tersedia online di http://www.catesol.org/06Jonckheere). Tanggal 7 Maret 2010.

Kelly, C. (1997). David Kolb, The Theory of Experiential Learning and ESL. Tersedia online di http: //iteslj.org/Articles/Kelly-Experiential/. Tanggal 9 Maret 2010.

Kusumargono, R.S. (2008). Efektivitas Pembelajaran Permainan Berbasis Komputer Dalam Meningkatkan Kosakata Bahasa Inggris. Tesis pada 
Sekolah Pascasarjana Universitas Pendidikan Indonesia Bandung: Tidak diterbitkan.

Laisou, F. (2008). Efektivitas Pembelajaran Menulis Dengan menggunakan Model The Experiential Approach. Tesis pada Sekolah Pascasarjana Universitas Pendidikan Indonesia Bandung: Tidak diterbitkan.

Leontiev, A. Psychology and Language Learning Process. Pergammon. London.

Nunan, David. (1992). Research Methode in Language Learning. New York: Cambride University Press.

Nunan, David. (1989). Designing Task for The Communication Language Classroom. Cambridge: Cambridge University Press.

Paul, David. (2007). Teaching English to Children in Asia. Hong Kong: Pearson Longman Asia ELT.

Richards, J.C dan Rodgers, T.S. (2001). Approaches and Methods in Language Teaching. Second edition. Cambridge: Cambridge University press.

Santrock, J.W. (1995). Perkembangan Masa Hidup (terjemahan). Jakarta: Erlangga.

Sugiono (2009). Metode Penelitian Pendidikan. Bandung: Alfabeta.

Sugiono (2006). Statistika Untuk Penelitian. Bandung: Alfabeta.

Sukmadinata, N.S. (2005). Metode Penelitian Pendidikan. Bandung: Remaja Rosda Karya.

Tarigan, H.G. (1981). Berbicara Sebagai Suatu Keterampilan Berbahasa. Bandung: Angkasa.

Tarigan, H.G. (1987). Teknik Pengajaran Keterampilan Berbahasa. Bandung: Angkasa.

Thornbury, Scott (2005). How to Teach Speaking. England: Longman

Uno, H.B. (2008). Model Pembelajaran, Menciptakan Proses Belajar Mengajar Yang Kreatif dan efektif. Jakarta: Bumi Aksara.

Zaini, H, Munthe, B dan Aryani, S.A. (2008). Strategi Pembelajaran Aktif. Yogyakarta: Pustaka Insan madani. 